whence with the obliquity of the ecliptic $=23^{\circ} 41^{\prime} \cdot 1$, Stone's places for A.D. $13^{8}$ become-

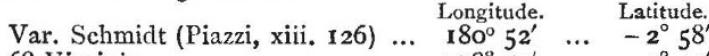

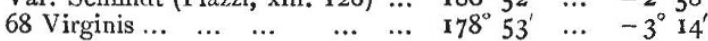

As we have seen, Ptolemy's I 9 th star of Virgo is placed in longitude $178^{\circ} \mathrm{o}^{\prime}$, latitude $-3^{\circ} \mathrm{o}^{\prime}$; but, as is well known, the longitudes of the Almagest are about one degree too small. Hence Schjellerup's identification of the variable with Ptolemy's star is likely to be correct; the object deserves frequent attention.

D'ARREST's COMET. - With reference to the remarks last week in this column on the first announcement of the observation of D'Arrest's comet in the Dun Echt Circular, Prof. Krueger, Director of the Observatory at Kiel, writes us from that establish went, as the "Centralstelle fuir astronomische Telegramme," as follows :- "I wish to state with reference to No. 703 , p. 589 , as I have done in $A . N$. No. 2507 [not yet received], that Dr. Hartwig had not telegraphed any daily motion of the supposed comet D'Arrest on the 4th April. The hypothetical daily motion was added by myself in the cable-telegram to Cambridge, U.S., because I assumed that the American astronomers were not in po-session of an ephemeris. Lord Crawford received, as usual, the same telegram as Cambridge, U.S., with the additional note (in order to avoid double.telegrams) that the telegram had been sent to America. European astronomers received only Dr. Hartwig's original communication."

\section{ON THE SENSE OF COLOUR AMONGST SOME OF THE LOWER ANIMALS ${ }^{1}$}

$A^{\mathrm{T}}$ the meeting of the Linnean Society on Thurday, A pril 19 , Sir John Lubbock read a paper on this subject. Some years ago M. Paul Bert made a series of interesting experiments with the conmon Dapbnia, or water-flea, which is so abundant in our ditches and pools. He exposed them to light of different colours, and he thought himself justified in concluding from his observations that their limits of vision at both ends of the spectrum are the same as our own, being limited by the red at one end, and the violet at the other.

In a previous communication Sir John Lubbock showed, on the contrary, that they are not insensible to the ultra-violet rays, and that at that end of the spectrum their eyes were affected by light which we are unable to perceive. These experiments have recently been repeated by $M$. Merezkowski, who, however, maintains that, though the Daphnias prefer the yellow rays, which are the brightest of the spectrum, they are, in fact, attracted, not by the coluur, but by the brightness; that, while conscious of the intensity of the light, they have no power to distinguish colours. Given an animal which prefers the brightest rays, it may seem difficult to distinguish between a mere preference for light itself rather than for any particular colour. To test this, however, Sir John Lubbock took porcelain troughs about an inch deep, eight inches long, and three broad. In these he put fifty Laphnias, and then, in a darkened chamber, threw upon them an electric spectrum arranged so that on each side of a giveu line the light was equal, and he found that an immense majority of the Daphnias preferred the green to the red end of the spectrum. Ayain, to select one out of many experiments, he took four troughs, and covered one-half of the first with a yellow solution, half of the second with a green solution, half of the thrrd with an opaque plate, and he threw over half of the fourth a certain amount of extra light by means of a mirror. He then found that in the first trough a large majority of the $\mathrm{Da}_{t}$,hnias preferred being under the yellow liquid rather than in the exposed half; that in the second a large majority preferred being under the green liquid rather than in the exposed half; that in the third a large majority preferred the exposed half to that which was shaded; and in the fourth that a large majority preferred the half on which the extra amount of light was thrown.

It is evident, then, that in the first and second troughs the Daphnias did not go under the solution for the sake of the shade, because other Daphnias placed by their side under similar conditions preferred a somewhat brighter light.

It seems clear, therefore, that they were able to distinguish the yellow and green light, and that they preferred it to white light. No such result was given with blue or red solutions. In such

${ }^{x}$ By Sir John Lubbock, Bart, , M.P. cases the Daphnias always preferred the uncovered half of the trough.

It is, of course, impossible absolutely to prove that they perceive colours, but these experiments certainly show that rays of various wave-lenuths produce distinct impressions on their eyes; that they prefer rays of light of such wave-lengths as produce upon our eyes the impression of green and yellow. It is, of course, possible that rays of different wave-lengths produce different impressions upon their eyes, but yet that such impressions differ in a manner of which we have no conception. This, how. ever, seems improbable, and on the whele, therefore, it certainly does appear that Daphnias can distinguish not only different degrees of brightnes:, but also differences of colour.

\section{UNIVERSITY AND EDUCATIONAL INTELLIGENCF}

CAMBridge.-Prof. Dewar commenced a short course on Chemical Technology in its relation to Organic Chemistry on April 23.

Mr. Sedgwick is lecturing on the Embryology of Mammals and Birds, and Mr. Caldwell on the Morphology of Gepbyrea, Brachiopoda, Polyzoa, Chøetognatha, and Larval Forms, practical work accompanying both courses.

Dr. Hans Gadow is lecturing on the Tegumentary and Muscular Systeus of the Vertebrata.

Prof. Darwin's lectures on the Theory of the Potential will include an account of Gauss's treatment of those problems generally associated with the name of Green.

The Demonstrator of Mechanism is giving a course of Mechanics applied to the strains in winding, pumping, and blast engines, and in other machines. A practical class is being formed for instruction in Surveying.

\section{SOCIETIES AND ACADEMIES LONDON}

Royal Society, April 12.- "Introductory Note on Communications to be presented on the Physiology of the Carbohycirates in the Animal System." By F. W. Pavy, M.D., F.R.S.

My last communication (Proc. Roy. Soc., vol, xxxii. p. 418) was entitled "A New Line of Research bearing on the Physiology of Sugar in the Animal System."

During the time which has since elapsed, I have been actively continuing my investigations in the direction started, and the re:ults obtained give an entirely new aspect to the whole subject of the physiolosy of the carbohydrates in the animal system.

Modern research has shown that, besides the well-known carbohydrate principles, such as sugar, \&c., there are several dextrins distinguishable by their optical properties and their cupric oxide reducing power.

From the colloidal principle starch, which has no cupric oxide reducing power, principles (dextrins) are producible by the action of ferments possessing gradually-increasirg cupric oxide reducing power until maltose is reached, which constitutes the final pro. duct, and which possess a little more than half the cupric oxide reducing power of glucose.

This is one foundation point connected with the researches I have been conducting upon the physiology of the carbohydrates in the animal system.

The other fuundation point is that the various members of the carbohydrate group are brought into glucose by the agency of sulphuric acid and heat.

Proceeding upon these facts, and taking the cupric oxide reducing power before and after subjection to the converting action of sulphuric acid and heat, I have prosecuted investigations upon the transformation of the carbohydrates within the animal system with the result of acquiring knowledge of an altogether unexpected nature.

Hitherto what has been observed as regards the transforma. tion of carbohydrates by the action of ferments and chemical agents, has been a change attended with increased hydrationfor example, the passage of starch into the successive forms of dextrin and maltose and cane-sugar into gluco:e.

The issue of the researches, however, which $I$ have been conducting recently, is to demonstrate the passage of carbohydrates exactly in the opposite direction by the action of certain ferments existing within the animal system.

Alike in the alimentary canal, the circulatory system, and the 
liver, the conditions exist by which this kind of transformation is effected.

From the mucous membrane of the alimentary canal a ferment is obtainable which converts (I) glucose into a body possessing the same kind of cupric oxide reducing power as maltose; (2) cane-sugar into maltose, and not glucose as formerly asserted and (3) starch either into maltose or a dextrin of low cupric oxide reducing power.

The presence of carbonate of soda modifies the action of a maltose-forming ferment, and leads to starcb passing into a dextrin of low cupric oxide reducing power instead of into maltose.

The portal blood contains a ferment which possesses a maltose or a dextrin-producing power, and the contents of the portal system during digestion are charged with a notable amount of maltuse sometimes, and at other times a low cupric oxide reducing dextrin.

After the introduction of glucose into the circulatory system, I have observed the presence of maltose.

The liver also contains a ferment canable, under certain conditions, of carrying glucose into maltose, and I have further witnessed, by the same kind of action as the sugars and dextrins are moved from one to the other, the conversion of a carbohydrate into the colloidal material belonging to the animal system (glycogen) which holds the analogous position of starch in the vegetable system.

Evidence has likewise been supplied that by an action of the same nature as that which moves the carbohydrates from one to the other in the carbohydrate group, they are, under certain conditions, carried into a body out of the group, and thence not susceptible of being brought into glucose by the converting action of sulphuric acid; and, on the other hand, under other conditions a substance is brought into the carbohydrate group, and its nature made recognisable by the converting action of sulphuric acid and its cupric oxide reducing power.

The subject as it even now presents itself is a large one, and I propose to deal with it in detail in a series of communications. The first will be devoted to that which refers to the alimentary canal.

Linneap Society, April 5.-Sir John Kirk, vice-president, in the chair.-Messrs. R. M. Barrington, G. E. ComerfordCasey, F. V. Dickins, and E. Cambridge Phillips were elected Fellows of the Society.-Mr. E. M. Holmes exhibired a specimen of birch-tree sap which had been found to exude frcm a cut branch one inch in diameter, at the rate of $4 \mathrm{oz}$. per hour during the night and $7 \mathrm{oz}$. to $8 \mathrm{oz}$. per hour during the day before the leaf buds had expanded, showing that the rapid rise of the sap was in this case not dependent on transpiration, but probably on endosmose accelerated by the expansion of the wood caused by solar heat. The sap had been collected and analysed by Dr. Attfield, and its contents recorded in the Pharmaceutical Fournal.-There was exhibited for Mr. R. Morton Middleton a well-marked example of wood showing the extensive ravages of the Isopod, Limnoria lignorum. The wood was from the pier piles of West Hartlepool, where the said Crustacean's depredations are very destructive.-The Secretary read a paper on the indiarubber-tree of the Gold Coast, by Capt. Alf. Moloney. In this the author stated that the Landolphia owariensis grows extensively in the countries of Akim, Aquapim, and Croboe; and he strongly recommended the natives and traders of Lagos to encourage rubber as an article of trade instead of solely depending as at present on palm oil. He described the habit of the live plant, and the method employed in extracting the rubber therefrom.-Mr. F. W. Phillips in a communication described a new species of freshwater Infusorian allied to the genus Gerda. It was proposed provisionally to name the new form G. coudata. It was obtained at Hertford, and in compary with the rotifer Ecistes pilula.-A paper was read on Hemicarex, Benth., and its allies, by Mr. C. B. Clarke; in this he gives a revision of the genera and species of Kobresia, Hemicarex, Schonoxiphium, and Uncinia.

Zoological Society, April 3.-St. George Mivart, F.R.S., vice-president, in the chair. - The Secretary read some extracts from a letter be had received from Mr. J. Sarbo in reference to the Gayal. The writer observed that Bos gaurus (the Gaur) and not Bos frontalis (the Gayal) is the Wild Ox of Assam, and that the $B$. frontalis is not known in a wild state, but only as a semidomesticated animal owned by various wild tribes from Assam to Arracan.-Mr. Sclater called the attention of the meeting to the skin of a Brown Crow from Australia, which had been sent to him for examination by Mr. Albert A. C. Le Souef, C.M.Z.S., and which he was inclined to regard as a variety in plumage of Corvus australis.-Mr. A. G. Butler read a paper containing an account of a collection of Indian Lepidoptera made by Lieut. Col. Charles Swinhoe, chiefly at Kurrachee, Solun, and Mhow. Thirty-two new species were described, and numerous field-notes by Col. Swinhe were incorporated in the paper.-Col. J. A. Grant read some notes on the Zebra met with by the Speke and Grant Expedition in the interior of Central Africa in 1860-63, which certainly belonged either to the true Zebra (Equus zebra) or to its clo ely allied northern form, the recently described Equus grevyi.

Meteorological Society, April 18.-Mr. J. K. Laughton, M.A.. F.R.A.S., president, in the chair.-T. G. Bowick, E. C. Clifton, H. Culley, Dr. W. Doberck, A. N. Pearson, Prof. H. Robinson, and J. E. Worth were elected Fellows of the Society.-The following papers were read:-On cirrus and cirro-cumulus, by the Hon. F. A. Rollo Russell, M. A., F.M.S. The author points out that next to frequent readings of the barometer and a knowledge of the distribution of atmospheric pressure, observation of the character of clouds, especially of cirrus, is of the greatest use in attempting to forecast coming weather. Observation of cirrus can plainly be made use of in a telegraphic system of weather forecasts as easily as observation of the barometer, and the employment of a number of scattered cirrus observers largely increases the probability of this form of cloud being noted. The paper contains a description of twelve different varieties of cirrus, with the weather they signify or at least precede, as observed by the author during the last eighteen years.- Some notes on waterspouts, their occurrence and formation, by George Attwood, F.G.S. 'This contains an account of several waterspouts observed in the Pacific Ocean, and also one seen in the Atlantic Ocean. The author believes that the waterspouts in the Pacific Ocean were caused by a cloud heavily charged with cooled moisture drifting from the high mountains of Costa Rica coning into contact with air-currents and clouds travelling in a different direction, and of a warmer temperature; by which contact the cloud heavily charged with moisture was given a rotatory motion, causing it to discharge part of its moisture and make it assume a cylin drical figure and fall down by its own gravity.-Records of bright sunshine, by W. W. Rundell, F.M.S. This is a discussion of the sunshine records made in the United Kingdom during the years 1881 and 1882 , from which it appears that there is more bright sunshine upon the coast than there is inland.-Note on wind, cloudiness, and halos; also on results from a Redier's barograph, by E. T. Dowson, F.M.S.-On the cold weather of March, 1883, by W. Marriott, F.M.S. The weather of this month will long be remembered for its very cold, dry, and windy character. The winter had been very mild, dull, and wet; and continued so to the beginning of March. A sudden change took place, however, on the 6th. A severe northerly gale set in on that day, accompanied with snow showers and a keen biting wind This gale was most violent in the North Sea, and caused sad havoc among the fishing fleet on the east coast, no less than 382 men and boys being drowned. The temperature fell considerably, the maximum being below $40^{\circ}$ almost all over the country, and in the North of England only a trifle above the freezing point. The same conditions prevailed for the next two or three days, the temperature however falling still lower, and on the Ioth the minimum occurred in the central and northern districts. The most remarkable weather of the month took place from the 2Ist to the 24th. Owing to a brisk fall of the barometer over France an easterly gale was experienced over this country, and as the temperature was low and the air very dry the wind was exceedingly bitter and keen, and its effect upon the human frame was most distressing.

\section{SYDNEY}

Linnean Society of New South Wales, February 28. C. S. Wilkinson, F.G.S., president, in the chair.-The following papers were read :-On the coal flora of Australia, by the Rev. J. E. Tenison-Woods, F.L.S., F.G.S., \&c. This was a complete monograph of all the known fossil coal plants, including the new species recently discovered by the author. A diagnosis of each genus and species was given, together with a history of the subject and its literature. The author also added his own views with reference to the classification, in which he regards some of the Newcastle beds as Pervian, some as Trias, and the Ipswich beds (Queensland), the Victorian carbonaceous 
(Bellerine, Cape Otway, Apollo Bay, Colac and the Wannon), Tasmanian (Jerusalem), and the Hawkesbury sandstone as Jurassic or Lower Oolite. He expresses a doubt whether the Wianamatta beds can be regarded as a distinct formation, his own opinion being that they are shales distributed at various levels all through the Hawkesbury sandstone. The new species of plants described are: Phyllotheca concinna, Equisetum rotiferum, Vertebraria tivoliensis, $V$. towarrensis, Sphenopteris (Aneimoides) fabellifolia, $S .(A) f$. var. erecta, Trichomanides laxum, T. spinifolium, Thinnfeldia media, T. australis, T. falcata, Alethopteris currani, Taniopteris carruthersi, Gleichenia (?) lineata, Feanpaulia bidens, Ptilophyllum oligonerum, Brachyphyllum crassum (which the author thinks may be a variety of B. manidare), Sequoiites australis, Walchia milneana, Cunninghamites australis. Besides these new species, the following Indian or Eu opean fossils are new to Australia:-Podozamites lanceolatus, Lindley and Hutton; Merianopsis major, Feist; Anoiopleridium ensis, Oldham. The monograph is meant to be a complete reference for students on the subject of Australian coal fossils, and is illustrated by six plates of heliographs and two of lithographs.--Further contributions to the flora of Queensland, by the Rev. B. Scortechini, F.L.S.-Descriptions of two new fungi, by the Rev. Carl Kalchbrenner. The specie described are Polyporus Pentzkei and Paxillus hirtulus, both from the Daintree River, Queensland.-Notes on the fructification of the Bunya Bunya in Sydney, by the Hon. James Norton, M.L.C.-Descriptions of some new fishes from Port Jackson, by E. P. Ramsay, F.L.S.-The President read some notes on the Tuena Gold Reefs, by M. F. Rate, mining engineer.

\section{BERLIN}

Physical Society, March 16.-Dr. Frülich exhibited a torsion galvanometer prepared in Messrs. Siemens and Halske's establishment for measuring electricity mechanically, in which the deflection of the magnetic needle is indicated by the corresponding torsion of a spring whose constant expansion power is known. The torsion galvanometer was at first constructed for measuring the current of the large dynamoelectric machine fitted up in Ocker for copper electroplating, and which at least resistance possesses a power of 800 amperes. Here it was impossible to employ either a dynamometer, owing to the irregularity of the mercurial contact, or a tangent compass, which has to be directly inserted in the main circuit. Hence measurement could be effected only by lateral closing, and as Dr. Frölich fully explained, the determination of the potential at any required number of points in the circuit, as rendered possible by the new apparatus, gives the data for ascertaining the electromotor strength, the resistance, and the power of the current. $\mathrm{He}$ described in great detail the construction and adjustment of the new appliance, in which, after insertion of determined resistances in the lateral circuit, the number of volts can be read off, and from these the amperes and ohms determined in the simplest manner. The torsion galvanometer is prepared in two forms, vertical with a magnet suspended to a cocoa tibre, and horizontal with a magnet resting on an edge. The latter form is intended especially for cases in which the apparatus undergoes no delicate manipulation.--Prof. Neesen briefly mentioned modifications which he has introduced both in the heat regulator used by him and in his ice calorimeter, illustrating them with diagrams. $\mathrm{He}$ bas found them work well in practice.

\section{PARIS}

Academy of Sciences, April 16.-M. Blanchard in the chair.-M. Jordan read a note on the works of the late Prof. $H$. Smith, and M. Bertrand added some remarks on the award of the mathematical prize.-Two new methods for determination of the right ascension of polar stars, and of the inclination of the axis of a meridian above the equator, by M. Lœwy.-Memoir on the temperature at the surface of the ground and of the earth to $36 \mathrm{~m}$. depth, as also of the temperature of two pieces of ground, one bare, the other covered with turf, during 1882 , by MM. Becquerel. This confirms previous results.-Graphic demonstration of a theorem of Euler concerning the partition of numbers, by Prof. Sylvester.-On the project of the interior African Sea, by.M. de Lesseps. After a visit to the region, he affirms (with several associates) the urgency and fea-ibility of the scheme.-M. Wolf was elected Member in the Section of Astronomy in place of the late M. Liouville.-On the evolution of malignant pustule in man and its treatment with iodised injections, by M. Richet. So long as general infection has not commenced, by bacteria or their spores entering the blood, active local treatment with tincture of iodine is efficacious.-Experiments on caustic anæsthesia, and observation of a case of ulcerated tumour of the breast operated with the aid of this method, by M. Guérin. A space was cauterised round the tumour with Vienna caustic and incised throughout; then the tumour was detached.-Mechanical action produced by magnets and by terrestrial magnetism (second memoir), by M. Le Cordier.-Calculus of a double integral, by $\mathrm{M}$. Callandreat,-Observations of the Swift-Brooks comet at Lyons Observatory, by M. Gonessiat.Law of periods (continued), by $M$. de Jonquières.-On the groups of transformations of linear differential equations, by $\mathrm{M}$. Picard.-On functions with lacunar spaces, by $M$. Poincaré.On a generalisation of the theorem of Fermat, by M. Picquet.-On the heat of combination of glycolates and the law of thermal constants of substitution, by $\mathbf{M}$. Tommasi.--On the liquefaction of oxygen and nitrogen, and on the solidification of sulphide of carbon and alcohol, by MM. Wroblewski and Olszewski. By making ethylene boil in vacuo, they obtained temperatures as low as $-136^{\circ} \mathrm{C}$. Liquid oxygen was obtained easily; it is colourless and transparent like carbonic acid; is very mobile and forms a very distinct meniscus. Sulphide of carbon freezes about $-116^{\circ} \mathrm{C}$. Alcohol solidifies (after being viscous about $-129^{\circ}$ ) about $-130^{\circ} \cdot 5$, forming a white body. Liquid nitrogen (colourless, and with visible meniscus) was obtained later.-Researches on phosphates, by MM. Hautefeuille and Margottet.On artificial Hausmannite, by $M$. Gorgeu.-On the chloride of pyrosulphuryl, by M. Konovaloff.-On the difference of reactional aptitude, \&c. (continued), by M. Henry.--Researches on the essence of Angelica of roots (Angelica officinalis), by M. Maudin.-Some effects of climate on the rapidity of growth of plants, by M. Capus. His measurements of various trees and shrubs in the botanical garden of Samarcand show the remarkable rapidity of growth there in April, May, and June.-Orientation of leaves with reference to light, by M. Mer. Certain parts of leaves (the birder generally) receive the luminous impression, while other parts (petioles, motor-enlargements) yerform the movements neces ary to place the former in a favourable position.-Contribution to the experimental study of the elongation of nerves, by M. Minor. He supports the view that this stretching is a purely local operation, a sort of incomplete section of a nerve.--Experimental studies on the physiological action of iodoform, by M. Kummo. - New experimental researches on the physiological action of veratrine, by MM. Pecholier and Redier. -The synthesis of the heavens and the earth, by M. Moigno. He deduces all from ether, first forming hydrogen. Universal gravitation is the direct effect of impulsions of ether.-A frontal clectric photophore, for medical use, was described by MM. Helot and Trouvé. It is an incandescent lamp, supplied from a bichromate battery, and fitted with a reflector and convergent lens. It is attached to the forehead.

\section{CONTENTS}

PAGE

ScIENTIFIC Worthiss, XXI.-WIL.IAM SpotTiswoode (With

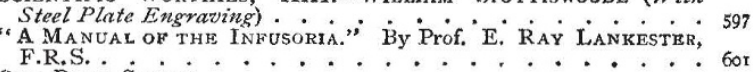
OUR BOOK SHELF:-

Griffith and Henfrey's "Micrographic Dictionary" . . . . . 603 LETTERS TO THE EDITOR :-

Speke and Grant's Zebra.-Sir J. FAYRER, K.C.S.I., F.R.S. . . 604 Leaves and their Environment.-GRANT ALLEN
Forms of Leaves. - Sir JOHN LUBBOCK, Bart., M.P. Forms of Leaves.-Sir JoHN LUBвоск, Bart., M.P. . . . * 605 The Zodiacal Light (?)-W. H. RoBINSON; RoBerT DwArRIS GriBnEY; E. B Kown; D. J. RowaN

On the Value of the "Neoarctic" as one of the Primary Zoological Regions.-Prof.-ANGELo HEILPRIN

Mock Moons.-F T. MoTT.

Benevolence in Animals - G . . . . 606

"Medioscribed Circle"-R. T.. J. RomANES, F.R.S . . . 607

Agriculturte in Madras. 0607

ANTHROPOLOGICAL NOTES IN THE Solomon IsLands. By SurgeonMajor H. B. GUPPY (With lllustration) . ON A FINE SPECIMEN OF APATITE FROM TYROL, LATELY IN THE

POSSESSION OF Mr. SAM' EL HENSON (With lllustration)
THE Evolution or THE AMERICAN TROTrING-HORSE. By W. THE Evolution OF THE AMERICAN TROT'TING-HORSE. By WM. H. 609

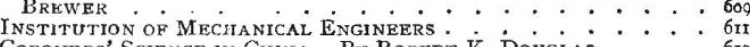
Coroners' Science in China. By Rober't K. Douglas . . . . 6iz

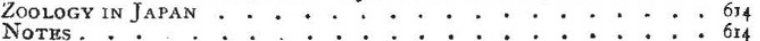
Notrs.

Schmidt's Variable Star near Spica . . . . . . . . . . . 6r D'Arrest's Comet . . . . . . . 6r ON THE SENSh OF COloUR AMONGST SOME OF the Lower ANimals.
By Sir John LubBock, Bart., M.P.

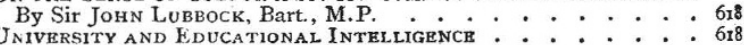

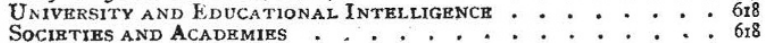

